\title{
RODZINY POMOCOWE - „MARTWY ZAPIS” W USTAWIE CZY REALNA POMOC PIECZY RODZINNEJ
}

\begin{abstract}
Assistant families - "dead record" in the Act on Family Support and Foster Care or real help for family custody

Poland, following the example of other European countries, has made significant changes to the system of child and family care. New solutions in the foster care system were introduced in the form of assistance families in order to support and temporarily replace foster carers.

Information on the assistance family was collected by means of internet research, mainly through thematic forums, chat rooms and social networking sites. However, it was extended during surveys in selected districts of the Lubelskie and Świętokrzyskie Voivodships. The respondents' opinions on the support families were not unequivocal, there were supporters and opponents of this idea, both among employees of social welfare institutions and interested substitute caregivers.
\end{abstract}

Key words: help family, foster care, help, support

\section{Wprowadzenie}

Dysfunkcje rodziny naturalnej skutkują pojawianiem się różnych form „sieroctwa”, które uważane jest za powszechny problem nie tylko w wymiarze pedagogicznym, lecz także społecznym, ekonomicznym czy psychologicznym. Pojawienie się tego zjawiska przyczynia się do poszukiwań opieki zastępczej dla dzieci dotkniętych tym problemem.

$\mathrm{Na}$ obecny system pieczy zastępczej składają się piecza rodzinna i instytucjonalna. Wśród form rodzinnych wymienia się: rodziny zastępcze (spokrewnione, niezawodowe, zawodowe, w tym pełniące funkcję pogotowia rodzinnego i specjalistyczne, oraz rodzinne domy dziecka). Natomiast formy instytucjonalne to: placówki opiekuńczo-wychowawcze, regionalne placówki opiekuńczo-terapeutyczne, interwencyjne ośrodki preadopcyjne ${ }^{1}$.

1 Ustawa o wspieraniu rodziny i systemie pieczy zastępczej, art. 34, art. 39, art. 93, Dz.U. z 2018 r. poz. 998, z późn. zm. (zm. Dz.U. z 2018 r. poz. 1544, Dz.U. z 2018 r. poz. 1076, Dz.U. z 2018 r. poz. 416 , M.P. z 2018 r. poz. 326). 
Dotychczasowe badania prowadzone wśród podopiecznych form rodzinnych i instytucjonalnych wskazują, że formy pieczy rodzinnej stanowią o wiele korzystniejsze środowisko opiekuńczo-wychowawcze niż nawet najlepiej zorganizowana placówka, która nie jest $\mathrm{w}$ stanie $\mathrm{w}$ pełni zaspokoić potrzeb dziecka czasowo niemogącego przebywać z rodzicami biologicznymi (Winogrodzka 2007; Łuczyński 2008; Ruszkowska 2013a; Basiaga 2014; Matejek 2015).

W Polsce od lat dziewięćdziesiątych XX wieku prowadzony jest proces deinstytucjonalizacji pieczy zastępczej, czyli zmniejszania liczby domów dziecka na rzecz placówek rodzinnych i rodzin zastępczych. Problematyka dotycząca opieki zastępczej wydaje się szczególnie ważna ze względu na zmiany dokonujące się w polskim systemie prawnym, przechodzącym liczne przeobrażenia, a jednocześnie dostosowującym się do standardów europejskich. Zmiany proponowane w projekcie nowelizacji Ustawy o wspieraniu rodziny i systemie pieczy zastępczej wynikają z ekologicznego podejścia do opieki nad dzieckiem - preferuje się przede wszystkim wsparcie rodziny i dziecka w ich naturalnym środowisku. Dzięki nowym przepisom ma nastąpić bardziej dynamiczny rozwój rodzinnych form pieczy zastępczej, tak aby zapewnić stabilne, rodzinne środowisko wychowawcze dzieciom pozbawionym opieki rodziców. Zaostrzono także zakaz umieszczania w pieczy instytucjonalnej dzieci młodszych - poniżej 10. roku życia².

Przyjmuje się, że jednostka funkcjonuje w środowisku w systemie różnych relacji indywidualnych, rodzinnych, lokalnych i globalnych (Kantowicz 2014: 108). Dlatego też wprowadzono rozwiązania dotyczące wsparcia rodziny dysfunkcyjnej (asystent rodziny, rodzina wspierająca, placówki wsparcia dziennego) oraz nowości w systemie pieczy zastępczej, to jest rodziny pomocowe, mające wspomagać i czasowo zastępować opiekunów zastępczych.

\section{Rodzina pomocowa w świetle regulacji prawnych i literatury}

Ustawa o wspieraniu rodziny i systemie pieczy zastępczej zakłada funkcjonowanie tak zwanej rodziny pomocowej, mającej na wniosek rodziny zastępczej czy prowadzącego rodzinny dom dziecka w określonych sytuacjach przejąć opiekę nad dziećmi. Za sytuacje te uważa się wypoczynek, udział w szkoleniach, pobyt w szpitalu, nieprzewidywane trudności czy zdarzenia losowe w rodzinie zastępczej lub rodzinnym domu dziecka.

Stanisław Nitecki i Aleksandra Wilk piszą, że rodzina pomocowa nie stanowi formy wsparcia dla pieczy rodzinnej w określonych pracach, lecz zastępuje te podmioty, przejmując pełną odpowiedzialność za powierzone im dzieci. Rodzina ta nie stanowi docelowej formy pieczy zastępczej, lecz jest instytucją mającą zapewnić ciągłość prawidłowej realizacji pieczy zastępczej (Nitecki, Wilk 2015: 351-352).

${ }^{2}$ Informacje na ten temat można znaleźć w projekcie ustawy o zmianie ustawy o wspieraniu rodziny i systemie pieczy zastępczej oraz niektórych innych ustaw: https://legislacja.rcl.gov.pl/projekt/12310806 (dostęp: 13.02.2018). 
Rodzinę pomocową mogą stanowić zarówno rodzina zastępcza niezawodowa, rodzina zastępcza zawodowa lub prowadzący rodzinny dom dziecka, jak i małżonkowie lub osoba niepozostająca w związku małżeńskim, przeszkoleni do pełnienia funkcji rodziny zastępczej, prowadzenia rodzinnego domu dziecka lub rodziny przysposabiającej. Należy przy tym zaznaczyć, że rodzina zastępcza zawodowa, rodzina zastępcza niezawodowa lub prowadzący rodzinny dom dziecka mogą przyjąć dziecko jako rodzina pomocowa bez względu na liczbę dzieci pozostających pod ich opiekąą. Zorganizowanie opieki nad dziećmi, w przypadku gdy rodzina zastępcza albo prowadzący rodzinny dom dziecka okresowo nie mogą sprawować opieki, należy do zadań organizatora rodzinnej pieczy zastępczej, który powinien taką informację pozyskać nie później niż 30 dni przed planowanym czasowym niesprawowaniem opieki. Należy podkreślić, że czas pobytu dziecka w rodzinie pomocowej nie może przekroczyć dwóch miesięcy.

W sytuacji gdy placówka rodzinna jest zdecydowana skorzystać ze wsparcia w postaci rodziny pomocowej, wówczas - jak pisze Beata Krajewska - najlepiej jest, gdy rodziną pomocową są osoby znane dzieciom, a opieka jest sprawowana w miejscu dotychczasowego zamieszkania, gdyż pozwala to uniknąć stresujących dla dzieci sytuacji lub je zminimalizować (Krajewska 2017: 131).

Kwestie finansowania rodzin pomocowych porusza się na różnych forach internetowych, między innymi na forum.ops.pl, gdzie możemy przeczytać, że:

świadczenia na pokrycie kosztów utrzymania dziecka, które przebywa w rodzinie pomocowej, nie są przyznawane na podstawie decyzji. Świadczenie na pokrycie kosztów utrzymania dziecka na mocy przepisów samej ustawy jest wypłacane bezpośrednio rodzinie pomocowej. Jednakże mogą istnieć sytuacje, że rodzina zastępcza nie będzie pobierać świadczenia. Wówczas rodzina pomocowa, w celu otrzymania świadczenia na pokrycie kosztów utrzymania dziecka, będzie musiała złożyć wniosek, a organ będzie musiał wydać decyzję, zapis ten jest zgodny z Ustawą o wspieraniu rodziny i systemie pieczy zastępczej .

Wypowiedź ta potwierdza, że zmianie ulega jedynie odbiorca wypłaty z rodziny zastępczej na rodzinę pomocową, natomiast kwoty nie ulegają zmianom i są uzależnione od długości pobytu dziecka w rodzinie pomocowej.

Z kolei na stronie wartowiedzieć.pl zamieszcza się informacje odnośnie do instytucji odpowiedzialnych za organizację wsparcia w postaci rodzin pomocowych, z których wynika, że:

Obowiązek zapewnienia rodziny pomocowej rodzinie zastępczej spoczywa na powiecie, na terenie którego funkcjonuje rodzina zastępcza, a w przypadku rodzin zastępczych zawodowych lub rodzinnych domów dziecka utworzonych na terenie innego powiatu na powiecie, który zawarł umowę z tą rodziną

${ }^{3}$ Ustawa o wspieraniu rodziny i systemie pieczy zastępczej, art. 74, Dz.U. z 2018 r. poz. 998, z późn. zm. (zm. Dz.U. z 2018 r. poz. 1544, Dz.U. z 2018 r. poz. 1076, Dz.U. z 2018 r. poz. 416, M.P. z 2018 r. poz. 326).

4 Tamże, art. 88. 
zastępczą lub rodzinnym domem dziecka. Powiat zobowiązany do finansowania pobytu dziecka w pieczy zastępczej powinien ponosić koszty świadczenia dla rodziny pomocowej ${ }^{5}$.

Warto wspomnieć o rozwiązaniach lokalnych, w niektórych miastach pojawiają się bowiem szczegółowe zarządzenia regulujące kwestie finansowania rodzin pomocowych; tak jest na przykład w m.st. Warszawa. Zarządzenie Nr 960/2017 Prezydenta Miasta Stołecznego Warszawy z dnia 30 maja 2017 roku w sprawie ustalenia wysokości świadczeń dla osób pełniących funkcję rodziny pomocowej ${ }^{6}$ określa kwoty, jakie otrzyma rodzina pomocowa za dobę pobytu w niej dzieci, przy czym kwota ta jest uzależniona od liczby dzieci pozostających pod opieką rodziny pomocowej. I tak: (a) 100 zł za dobę - w przypadku sprawowania opieki nad jednym dzieckiem, (b) 130 zł za dobę - w przypadku sprawowania opieki nad dwójką dzieci, (c) 160 zł za dobę - w przypadku sprawowania opieki nad trójką i więcej dzieci, (d) w przypadku umieszczenia w rodzinie pomocowej więcej niż trójki dzieci świadczenie jest zwiększane o 30 zł proporcjonalnie do liczby dni pobytu dzieci w rodzinie pomocowej. Ponadto w przypadku gdy umowa o pełnienie funkcji rodziny pomocowej jest wykonywana w sobotę, niedzielę lub dni ustawowo wolne od pracy, to świadczenia są zwiększane o 50 zł za każdy z wyżej wymienionych dni. Nieco inaczej te kwestie reguluje m. Kraków, w którym za pozostawanie rodziną pomocową przez 30 dni zawodowe rodziny zastępcze pełniące funkcję pogotowia rodzinnego dla jednego dziecka otrzymują wynagrodzenie w wysokości 1085 zł brutto, dla dwojga dzieci - 1350 zł brutto, dla trojga zaś - 1540 zł brutto. W przypadku rodzin niezawodowych wynagrodzenie wynosi 1000 zł brutto ${ }^{7}$.

Nieliczne publikacje na temat rodzin pomocowych zamieszczane są głównie w prasie lokalnej, a wynika $\mathrm{z}$ nich, że niewielu opiekunów zastępczych decyduje się na ich pomoc - wnioski takie płyną między innymi z wypowiedzi dyrektorów OPS: „większość $\mathrm{z}$ rodzin, gdy była informowana o prawie do wypoczynku, wskazywała wprost, że nie wyobraża sobie wyjazdu na urlop i pozostawienia dzieci”. Dyrektor PCPR w Olsztynie zwrócił uwagę, że „nie wszędzie działające rodziny zastępcze mogą jednocześnie pełnić funkcję pomocową, bo mają pod swoją opieką maksymalną liczbę dzieci, w konsekwencji mogłoby się okazać, że dziecko musiałoby trafić do placówki opiekuńczo-wychowawczej, a to nie byłoby dla niego korzystne"

${ }^{5} \mathrm{http}: / /$ wartowiedziec.pl/polityka-spoleczna/16215-zapewnienie-rodziny-pomocowej (dostęp: 21.01.2018).

${ }^{6}$ Zarządzenie Nr 960/2017 Prezydenta Miasta Stołecznego Warszawy z dnia 30 maja 2017 roku w sprawie ustalenia wysokości świadczeń dla osób pełniących funkcję rodziny pomocowej na podstawie art. 92 ust. 1 pkt 2 i ust. 2 Ustawy z dnia 5 czerwca 1998 roku o samorządzie powiatowym (Dz.U. z 2016 r. poz. 814,1579 i 1948 oraz Dz.U. z 2017 r. poz. 730), oraz art. 75, art. 85 ust. 6, ust. 7 i ust. 8, art. 180 pkt 4 i art. 191 ust. 7 Ustawy z dnia 9 czerwca 2011 roku o wspieraniu rodziny i systemie pieczy zastępczej (tekst jednolity Dz.U. z 2017 r. poz. 697).

7 Zarządzenie Nr 3003/2015 Prezydenta Miasta Krakowa z dnia 9 listopada 2015 r., https://www.bip. krakow.pl/_inc/rada/posiedzenia/show_pdfdoc.php?id=79458 (dostęp: 13.02.2019).

${ }^{8}$ Informacje na http://praca.gazetaprawna.pl/artykuly (dostęp: 23.01.2018). 
Istotne znaczenie mają także dane statystyczne dotyczące liczebności rodzin pomocowych. Z zestawień zamieszczonych w Informacji Rady Ministrów o realizacji w roku 2016 Ustawy o wspieraniu rodziny i systemie pieczy zastępczej wynika, że najmniej rodzin pomocowych funkcjonowało w województwie podlaskim - 3 rodziny pomocowe, podkarpackim - 5 rodzin pomocowych, opolskim - 6, lubelskim i świętokrzyskim - po 10 rodzin pomocowych. Natomiast $\mathrm{w}$ tych województwach, w których jest tych rodzin więcej, na przykład łódzkim (30 rodzin pomocowych), nie funkcjonują one we wszystkich powiatach. Rodziny pomocowe na terenie województwa łódzkiego w 2017 roku funkcjonowały w 9 powiatach, w 15 zaś ich nie było 9 .

Z kolei dane zamieszczone w Informacji Rady Ministrów o realizacji w roku 2017 Ustawy o wspieraniu rodziny i systemie pieczy zastępczej pozwalają stwierdzić, że spośród 2654 rodzin zastępczych zawodowych i rodzinnych domów dziecka z usług rodzin pomocowych w 2017 roku skorzystały 462 uprawnione do formy pieczy rodzinnej, co stanowi tylko $17,40 \%$ zawodowych rodzin zastępczych i rodzinnych domów dziecka.

Z cytowanych powyżej dokumentów wynika, że niektóre miasta i powiaty realizują zapisy ustawy dotyczące powoływania rodzin pomocowych, inne zaś z różnych powodów nie wywiązują się ze swych zadań, co może wynikać z przyczyn finansowych albo też z powodu braku chętnych do sprawowania tak trudnej funkcji.

Pomysł wprowadzenia rodzin pomocowych do systemu pieczy zastępczej należy rozpatrywać zarówno pod kątem jego zalet, jak i wad. Czasowy odpoczynek, urlop zapewne miałyby nie dopuścić do wypalenia zawodowego czy po prostu „zawód” opiekuna zastępczego postawić na równi $\mathrm{z}$ innymi profesjami. $\mathrm{Z}$ kolei należy pamiętać jednak, że osoby decydujące się na wykonywanie tak trudnej roli muszą mieć świadomość, że obowiązków przez nich wykonywanych nie można traktować jak zwyczajnej pracy, do czynienia mają bowiem z dziećmi niejednokrotnie boleśnie dotkniętymi przez los, nie można więc traktować ich przedmiotowo, dając im po prostu zastępstwo. Korzystniejsze wydaje się chociażby finansowanie przez powiaty dzieciom wyjazdów wakacyjnych, a tym samym odciążanie rodziców w tym czasie od obowiązków opiekuńczo-wychowawczych (Ruszkowska 2013b: 53).

\section{Rodzina pomocowa w świetle własnych badań i analiz}

Informacje na temat rodziny pomocowej zebrano poprzez autorską analizę zapisów na forach internetowych, głównie forach tematycznych ${ }^{10}$, oraz portalach społecznościowych. W dyskusjach za pośrednictwem Internetu pozyskano informacje z różnych regionów kraju (Warmia i Mazury, Małopolska, Mazowsze, Lubelszczyzna,

9 Informacja na temat stanu pieczy zastępczej w województwie łódzkim 2017; http://www.rcpslodz. pl/images/Pobieranie/2017_07_11_Raport_2017_stan_pieczy_zastepczej_w_woj_lodzkim.pdf(dostęp: 19.01.2019).

${ }_{10}$ Autorskim analizom poddano fora internetowe, to jest forum.gazeta.pl oraz forum.ops.pl. 
Podlasie, Pomorze, Śląsk). Analizom poddano argumenty za i przeciw korzystaniu ze wsparcia w postaci rodzin pomocowych. Tematykę podjęto ze względu na zainteresowania autorki. Ponadto w czwartym kwartale $2017 \mathrm{i}$ trzecim kwartale 2018 roku informacje na temat rodzin pomocowych poszerzono w trakcie badań sondażowych. Przeprowadzono je na terenie wybranych powiatów województwa lubelskiego i świętokrzyskiego w placówkach opiekuńczo-wychowawczych o charakterze rodzinnym i w rodzinnych domach dziecka. Materiał badawczy pozyskano dzięki wywiadom częściowo ustrukturyzowanym z osobami prowadzącymi te placówki. Wywiad przeprowadzono w 3 placówkach opiekuńczo-wychowawczych typu rodzinnego na terenie województwa lubelskiego oraz 5 rodzinnych domach dziecka ( 2 w województwie lubelskim i $3 \mathrm{w}$ świętokrzyskim). W trakcie wywiadu pytano o funkcjonowanie rodzin pomocowych na terenie poszczególnych powiatów, częstotliwość korzystania z ich pomocy oraz opinię na ich temat.

Podczas analizy forów tematycznych oraz za pośrednictwem portali społecznościowych pojawily się wypowiedzi przeciw powoływaniu rodzin pomocowych:

- Myśle, że wszystko zależy od ludzi. Znam przypadki rodzin zastępczych, gdzie dzieci są bo sq̨. A sq rodziny, gdzie dzieci sq ważne, uczy się je, jak prawidłowo funkcjonuje rodzina, jak się nawzajem wspierać, pomagać sobie czy brać odpowiedzialność za podejmowane przez siebie decyzje. Nie można w takich sytuacjach wziąc sobie po prostu wolnego (wypowiedź pracownika OPS).

- Zwykle dużo czasu zajmuje rodzicom zastępczym i dzieciom zbudowanie relacji. Trudno sprostać opiece nad kilkorgiem dzieci. Rodzinie zapewnia się oczywiście różnego rodzaju wsparcie, np. psychoterapeutyczne, oferuje się szkolenia, superwizje, czasami zatrudnia osobę wspomagajacca. Niejednokrotnie istnieja obawy pracowników socjalnych, czy rodzinie się uda stworzyć dzieciom odpowiedni dom, czy rodzice się nie wypala. Dobrze by było wysłać ich raz na jakiś czas na zastużony odpoczynek, ale $z$ drugiej strony co $z$ tak trudno budowanymi relacjami, czy nie zostałyby zaburzone i ponownie trzeba by je budować? (wypowiedź pracownika placówki opiekuńczo-wychowawczej).

- Jest wiele zawodów na świecie, a sednem bycia rodzina zastępcza jest to, by dzieci nie plataly się po pogotowiach opiekuńczych i domach dziecka. Dlatego uważam, $\dot{z} e$ urlop $w$ innym terminie niż wcześniej ustalony wyjazd dziecka powinien być niemożliwy w tym „zawodzie”.1.

- Rodzina zastępcza to nie przechowalnia bagażu, tylko azyl dla skrzywdzonych dzieci. Jeżeli ktoś tego nie rozumie, to niech lepiej nie podchodzi do tematu, $z$ którejkolwiek strony ${ }^{12}$.

Drugą grupę stanowily wypowiedzi za powoływaniem rodzin pomocowych:

- Zawodowych rodzin (tych $z$ prawdziwego zdarzenia, zaangażowanych i dobrych ludzi) jest niewiele. Niestety, nie mam dobrych doświadczeń z tymi rodzinami.

${ }^{11}$ http://forum.gazeta.pl/forum (dostęp: 22.01.2018).

12 Tamże. 
W moim rejonie była rodzina, która niby spełniała wszystkie warunki, a jednak kobieta stosowała przemoc wobec swoich podopiecznych. Sprawa w sadzie nadal się toczy. Jestem zdania, że odpowiednim wyjściem sa rodzinne domy dziecka. Atmosfera $i$ warunki jak $w$ domu, ale profesjonalna opieka i monitoring z zewnątrzjednak konieczne jest zapobieganie wypaleniu $i$ korzystanie $w$ tym celu ze wsparcia rodzin pomocowych (wypowiedź pracownika OPS).

- Sa rodziny zastępcze zawodowe petniące funkcje pogotowia, czyli takie, w których dzieci z założenia sa czasowo, przez czas trwania postępowania, góra rok i 3 miesiące. Rotacja dzieci jest dość duża, ich rola jest zapewnienie im przyjaznych warunków, ale z góry wiadomo, że dziecko nie będzie tam na zawsze. To bardzo ciężka i wyczerpujaca praca, bo trafiaja tam dzieci w sytuacji kryzysowej, poobijane przez życie i rodziców. Tym ludziom należy się urlop jak mało komu, bo pracuja 24 godziny na dobę, 7 dni w tygodniu, najczęściej mają pod opieka 2-4 dzieci i nie widzę nic zdrożnego w tym, że mają urlop - czasem może potrzebuja się zresetować, pobyć tylko we dwoje, wyspać, zejść z catodobowego dyżuru, pojechać do swoich rodzin albo za granice i nie mogą, nie musza zabierać podopiecznych. Te rodziny zazwyczaj maja pełne „obłożenie”, miejsc w nich jest ciagle za mało i może się niestety tak zdarzyć, że dziecko na czas urlopu musi iść do placówki, i to nie jest fajne, ale te forumki, które uważają, że urlop $w$ tej sytuacji to fanaberia, zapraszam do najbliższej opieki społecznej-zgłoście się jako kandydatki! Fajna robota i można nawet 2 tysiace zarobić! Rodziny tzw. długoterminowe zazwyczaj bardziej związują się z dziećmi i spędzają wakacjel urlopy razem $z$ nimi $^{13}$.

- Rodzina zastępcza ma prawo do 30 dni urlopu w roku, ale oddanie dziecka do pogotowia opiekuńczego to ostateczność, gdy nie ma innych opcji opieki nad dzieckiem. Inna rzecz to ocena moralna zastępczych rodziców, którzy dopuszczają taka możliwość (wypowiedź pracownika placówki opiekuńczo-wychowawczej).

Wypowiedzi nie były jednoznaczne. Wśród pracowników instytucji pomocy społecznej i placówek opiekuńczo-wychowawczych zdarzali się zarówno zwolennicy, jak i przeciwnicy powoływania rodzin pomocowych. Podawali oni argumenty za ich funkcjonowaniem i przeciwko. Główny argument przemawiający za korzystaniem ze wsparcia rodzin pomocowych to zapobieganie wypaleniu zawodowemu, a przeciwko to przedmiotowe traktowanie podopiecznego pieczy zastępczej.

Z kolei w trakcie badań realizowanych na terenie województwa lubelskiego i świętokrzyskiego pozyskano następujące wypowiedzi osób prowadzących rodzinne domy dziecka i placówki rodzinne:

- Rodziny pomocowe to fikcja, na naszym terenie nikt z osób prowadzacych rodzinne domy dziecka czy rodziny zastępcze nigdy nie byt na urlopie (województwo lubelskie, placówka rodzinna).

13 Tamże. 
- My prowadzimy rodzinny dom dziecka od 14 lat i tyle czasu nie mieliśmy nawet dnia wolnego, bo nie ma nas kto zastąpić (województwo lubelskie, rodzinny dom dziecka).

- Nie ma osób chętnych do pelnienia zastępstwa w czasie, kiedy my mielibyśmy mieć wolne, i wcale się nie dziwię, nie jest łatwo przejąć odpowiedzialność za czyjeś dzieci (województwo lubelskie, rodzinny dom dziecka).

- Jeśli chodzi o rodzinę pomocową, to nigdy nie korzystaliśmy, chociaż placówkę prowadzimy kilkanaście lat. W naszym powiecie był kiedyś pomysł i podobno nawet byli chętni, ale z tego, co wiem, to takiej rodziny nie ma obecnie (województwo świętokrzyskie, rodzinny dom dziecka).

- Zazwyczaj brak jest rodzin przeszkolonych oczekujacych na dziecko, nie ma też zbyt dużego zainteresowania stanowieniem pieczy rodzinnej, te rodziny czy rodzinne domy dziecka, które funkcjonują, „maja zazwyczaj pełne obłożenie podopiecznymi" (województwo świętokrzyskie, rodzinny dom dziecka).

Należy podkreślić, że placówki rodzinne i rodzinne domy dziecka, do których udało się dotrzeć w czasie badań sondażowych, były usytuowane głównie w małych powiatach, często na terenach wiejskich, co mogło mieć przełożenie na brak wsparcia w postaci rodzin pomocowych.

Badani opiekunowie nie byli do końca przekonani o słuszności powoływania rodzin pomocowych, twierdzili bowiem:

dziecko to nie bagaż, nie można go oddać na przechowanie (wypowiedź się powtarzała w obu województwach, niemal we wszystkich badanych placówkach).

Dlatego też respondenci zgodnie proponowali swoje rozwiązania odnośnie do chociażby kwestii wypoczynku:

jeśli wypoczywamy, to zazwyczaj z dziećmi, ewentualnie jeden z opiekunów wyjeżdża, a drugi zajmuje się dzieciakami; dobra alternatywa, zwłaszcza w przypadku posiadania podopiecznych w wieku szkolnym, jest posyłanie ich w tym samym czasie na kolonie, obozy czy inne formy wypoczynku po to, by mieć chwile dla siebie.

Z danych zamieszczanych cyklicznie w Informacji Rady Ministrów wynika, że zarówno województwo lubelskie, jak i świętokrzyskie dysponują małą liczbą rodzin pomocowych w stosunku do liczby rodzinnych domów dziecka i rodzin zastępczych zawodowych. W związku z tym badane osoby prowadzące placówki rodzinne i rodzinne domy dziecka stwierdzały, że: musza sobie radzić sami z kwestiami, takimi jak organizacja wypoczynku czy nawet zastępstwo na czas choroby, najczęściej korzystając z pomocy bliskich (dziadków, cioć, wujków etc.), tak jak się to robi w każdej rodzinie naturalnej. 


\section{Podsumowanie}

Wśród głównych przyczyn ograniczonego funkcjonowania rodzin pomocowych w systemie pieczy zastępczej należy wymienić:

- Zbyt małą liczbę osób chętnych do sprawowania rodzinnej pieczy zastępczej, co może być warunkowane faktem, że praca opiekunów zastępczych jest związana $\mathrm{z}$ ciągłym przezwyciężaniem trudnych, często kryzysowych czy traumatycznych sytuacji wynikających z wcześniejszych negatywnych doświadczeń podopiecznych (Ruszkowska 2013b: 96).

- Maksymalną liczbę dzieci przebywających pod opieką opiekunów zastępczych (w związku z brakami chętnych do sprawowania rodzinnej pieczy zastępczej dzieci umieszcza się w placówkach, które już funkcjonują).

- Brak rodzin przeszkolonych i oczekujących na dziecko (zazwyczaj rodzina przeszkolona, zakwalifikowana do pełnienia funkcji rodziny zastępczej czy rodzinnego domu dziecka nie musi oczekiwać na umieszczenie w niej podopiecznych).

- Niezbyt wysokie wynagrodzenie (wynagrodzenie nieadekwatne do nakładu pracy związanego z opieką i wychowaniem podopiecznych pieczy zastępczej).

- Niechęć ze strony osób prowadzących placówki rodzinne do pozostawiania swoich podopiecznych pod opieką innych osób.

Sam pomysł powoływania rodzin pomocowych wydaje się mieć zarówno zwolenników, jak i przeciwników tak wśród pracowników instytucji pomocy społecznej, jak i samych opiekunów zastępczych. Skoro jednak zapis w ustawie się pojawił, dobrze by było, aby ta forma wsparcia pieczy rodzinnej funkcjonowała na szerszą skalę, szczególnie tam, gdzie jest wola do skorzystania z urlopu, wypoczynku, a brakuje osób chętnych do tego, by zapewnić opiekunom zastępstwo. Warto by było przeprowadzić szersze analizy dotyczące występowania i funkcjonowania rodzin pomocowych. Należałoby się przyjrzeć problemom zgłaszanym w środowiskach lokalnych, zwłaszcza w mniejszych i biedniejszych powiatach.

\section{Bibliografia}

Basiaga J. (2014). Zawodowa miłość. O opiece nad dziećmi w pogotowiach rodzinnych. Wydawnictwo Akademickie „Żak”, Warszawa.

file://C:/Users/To_Ja/Downloads/Inf\%20RM\%20nt.\%20pieczy\%20za\%202015\%20r\%20(1). pdf (dostęp: 26.01.2018).

http://forum.gazeta.pl/forum/w,567,149749565,149749565,rodzice_zastepczy.html\#p149760142 (dostęp: 22.01.2018).

http://forum.ops.pl/viewtopic.php?t=207154330\&p=207184559 (dostęp: 24.01.2018).

https://legislacja.rcl.gov.pl/projekt/12310806 (dostęp: 13.02.2019).

http://praca.gazetaprawna.pl/artykuly/626050,rodzice-zastepczy-moga-isc-na-urlop-jednak-niewielu-na-to-sie-decyduje.html (dostęp: 23.01.2018). 
http://wartowiedziec.pl/polityka-spoleczna/16215-zapewnienie-rodziny-pomocowej (dostęp: 21.01.2018).

https://www.bip.krakow.pl/_inc/rada/posiedzenia/show_pdfdoc.php?id=79458 (dostęp: 13.02.2019).

http://www.rcpslodz.pl/images/Pobieranie/2017_07_11_Raport_2017_stan_pieczy_zastepczej_w_ woj_lodzkim.pdf (dostęp: 19.01.2019).

Informacja Rady Ministrów o realizacji w roku 2016 Ustawy z dnia 9 czerwca 2011 r. o wspieraniu rodziny i systemie pieczy zastępczej, Dz.U. z 2017 r. poz. 697, z późn. zm.

Informacja Rady Ministrów o realizacji w roku 2017 Ustawy z dnia 9 czerwca 2011 r. o wspieraniu rodziny i systemie pieczy zastępczej, Dz.U. z 2018 r. poz. 998, z późn. zm.

Kantowicz E. (2014). Praca socjalna z rodzina ryzyka, w: M. Ruszkowska, M. Winiarski (red.), Praca socjalna z dziećmi, młodzieżą i rodziną. CRZL, Warszawa: 99-118.

Krajewska B. (2017). Rodziny pomocowe jako forma wsparcia rodzin zastępczych i rodzinnych domów dziecka, file://C:/Users/To_Ja/Downloads/Rodziny\%20pomocowe\%20jako\%20 forma\%20wsparcia\%20rodzin\%20zast\%20pczych\%20i\%20rodzinnych\%20dom\%C3\%B3w\%20 dziecka\%20(3).pdf (dostęp:19.01.2019).

Łuczyński A. (2008). Dzieci w rodzinach zastępczych i dysfunkcjonalnych. KUL, Lublin.

Matejek J. (2015). Dziecko w środowisku rodzinnej pieczy zastępczej, w: T. Biernat, J.A. Malinowski, K.M. Wasilewska-Ostrowska (red.), Rodzina w pracy socjalnej-aktualne wyzwania i rozwiąania. Wydawnictwo AKAPIT, Toruń: 195-206.

Nitecki S., Wilk A. (2015). Ustawa o wspieraniu rodziny i systemie pieczy zastępczej. Komentarz. Wolters Kluwer, Warszawa.

Ruszkowska M. (2013a). Diagnoza rodzin zastępczych w obliczu dylematów współczesności. CRZL, Warszawa.

Ruszkowska M. (2013b). Rodzina zastępcza jako środowisko opiekuńczo-wychowawcze. CRZL, Warszawa.

Ustawa o wspieraniu rodziny i systemie pieczy zastępczej, Dz.U. z 2018 r. poz. 998 z późn. zm. Winogrodzka L. (2007). Rodziny zastępcze i ich dzieci. UMCS, Lublin.

Zarządzenie Nr 960/2017 Prezydenta Miasta Stołecznego Warszawy z dnia 30 maja 2017 roku w sprawie ustalenia wysokości świadczeń dla osób pełniących funkcję rodziny pomocowej. 